\author{
Софія Березка, \\ асистент кафедри \\ практичної психології \\ ДВНЗ «Донбаський державний \\ педагогічний університет» \\ E-mail: berezka.sonya@gmail.com \\ ORCID 0000-0001-8716-2712 \\ Assistant Lecturer of the Department \\ of Practical Psychology \\ SHEI «Donbas State Pedagogical \\ University»
}

\title{
ОСОБЛИВОСТІ ПСИХОДІАГНОСТИКИ ПОВЕДІНКОВИХ РОЗЛАДІВ ДОШКІЛЬНИКІВ 3 ПОРУШЕННЯМ ІНТЕЛЕКТУАЛЬНОГО РОЗВИТКУ
}

\begin{abstract}
Дослідження поведінкових розладів дошкільників з порушеннями інтелектуального розвитку розглянуто як невід'ємну складову психологічного супроводу дітей, а отримані діагностичні дані - як основу для здійснення подальшої ефективної психокорекційної роботи. Обтрунтовано необхідність створення комплексного та трунтовного підходу до діагностики особливостей поведінкових розладів старших дошкільників з інтелектуальними порушеннями. Проаналізовано сучасні наукові дослідження $і$ визначено, що поведінкові розлади дітей з порушеннями інтелектуального розвитку досліджуються з погляду біологічного, соціального та психолого-педагогічного підходу. У статті феномен поведінкових розладів розглянуто в межах психолого-педагогічного підходу, зазначено його переваги. Визначено, щяо найбільш поширеним видом поведінкових розладів серед дітей дошкільного віку з порушеннями інтелектуального розвитку є агресивна поведінка. Виділено основні критерії для діагностики агресивної поведінки дошкільників з порушеннями інтелектуального розвитку, а саме: рівень самоконтролю, тип локусу контролю, рівень дисципліни, риси особистості, особливості емоційної сфери та взаємин дочкільників. До кожного критерію підібрано психодіагностичні методики з урахуванням особливостей дітей дошкільного віку з порушеннями інтелектуального розвитку. Представлено результати діагностики за кожним критерісм. На основі отриманих даних визначено рівні сформованості агресивної поведінки у дітей старшого дошкільного віку з порушеннями інтелектуального розвитку. Наведено характеристики дітей старшого дошкільного віку з порушеннями інтелектуального розвитку з високим, середнім і низьким рівнем сформованості агресивної поведінки.
\end{abstract}

Ключові слова: поведінкові розлади, діти дошкільного віку з порушеннями інтелектуального розвитку, агресивна поведінка, біологічний та психолого-соиіальнопедагогічний підхід.

The research of behavioral disorders of preschool children with intellectual disabilities is an integral part of the psychological support of children, and the diagnostic data obtained are the basis for further effective psycho-corrective work. Therefore, it is necessary to create an integrated and thorough approach for the diagnosis of behavioral disorders of older preschool children with intellectual disabilities. Approach to behavioral disorders only as a nosological unit significantly restricts the process of psychological assistance to children with intellectual disabilities. Therefore, it is important to search for new approaches to the perception of the essence and characteristics of behavioral disorders. The article covers the understanding of behavioral disorders in terms of psychological and pedagogical approach. Contemporary studies of behavioral disorders of preschool children with intellectual disabilities indicate that aggressive behavior is the most destructive and widespread manifestation of behavioral disorders among children. The article analyzes aggressive behavior of children of preschool age with a violation of intellectual development as one of types of behavioral disorders. The main criteria for diagnosing aggressive behavior are identified: the level of self-control, the type of control locus, the level of discipline, personality traits, features of the emotional sphere and the relationship 


\section{Psychology}

between preschooler and others. Each criterion chosen diagnostic techniques are adapted to the peculiarities of children with intellectual disabilities. In particular, the research used projective techniques ("Cactus», Rene Gill's technique), expert evaluation (questionnaires of educators, correctional teachers, psychologists and parents of children), test methods ("Chain of Action», "Once»), observation and collection of anamnesis. The results of diagnostics of the experimental and control group of the studied children of preschool age with violation of intellectual development according to each criterion are presented. Based on the obtained data, the levels of aggressive behavior in children of the senior preschool age with intellectual disabilities are determined. The characteristics of children with intellectual disabilities with high, moderate and low levels of aggressive behavior are given.

Keywords: behavioral disorders, children of preschool age with intellectual disabilities, aggressive behavior, biological and psycho-socio-pedagogical approach.

Постановка проблеми. У сучасній науці поведінкові розлади досліджуються з точки зору двох протилежних підходів - біологічного та психолого-соціально-педагогічного [Дидактичні та методичні засади..., 2014; Руденко, 2010]. Розгляд поведінкових розладів як окремої нозологічної одиниці (біологічний підхід) обмежує діяльність психолога 3 психокорекційної та психодіагностичної роботи, оскільки визначає поведінкові розлади як захворювання, що не входить до компетенції психолога. У свою чергу, психолого-соціально-педагогічний підхід досліджує поведінкові розлади як види поведінки, що відхиляються від норми (але не є патологією), а вирішальним фактором їхнього розвитку $є$ соціальне середовище та психічний розвиток самої дитини. У рамках дослідження дітей $з$ порушенням інтелектуального розвитку даний підхід дозволяє розглядати розлади поведінки не як самостійний діагноз, а як прояви та наслідки супутнього психічного порушення, які є соціально або психологічно детермінованими і відносяться до сфери діяльності психологічних служб. Таким чином, практичний психолог, враховуючи особливості розвитку дошкільників 3 порушенням інтелектуального розвитку, може корегувати соціальне оточення, педагогічний вплив 3 метою упередження розвитку поведінкових розладів, а також самостійно проводити діагностику та психокорекцію розладів поведінки. Врахування специфіки психічного розвитку дитини 3 органічним ураженням кори головного мозку та впливу на неї соціального оточення дозволяє комплексно та грунтовно організувати психологічний супровід дошкільників 3 поведінковими розладами.

Сучасні дослідження поведінкових розладів дошкільників 3 порушенням інтелектуального розвитку свідчать про те, що найбільш деструктивним та розповсюдженим проявом поведінкових розладів серед дітей є агресивна поведінка [Дидактичні та методичні ..., 2014; Психологія розумово..., 2008; Руденко, 2012]. Саме тому вивчення агресивної поведінки як одного з видів поведінкових розладів дітей дошкільного віку 3 порушенням інтелектуального розвитку набуває сьогодні особливої актуальності.

Аналіз останніх досліджень $\boldsymbol{i}$ публікацій. Сучасні концепції поведінкових розладів представлено в працях Е.Гура, Т.Журжу, 
Ю. Клейберг, В. Ковальова, С. Позднякова, О. Родинського, Л. Руденко, Г. Сухарева, М. Федоренко та ін.; вчення про поведінку, що відхиляється, у дітей 3 порушеннями інтелектуального розвитку висвітлено у дослідженнях І І. Григор'євої, І І. Гладченко, Г. Запрягаєва, О. Коган, I. Коробейникова, В. Корольова, О. Ляшенко, Н. Макарчук, М. Матвєєвої, В. Мельниченко, О. Сєверова, В. Синьова, I. Піскунова, І. Ужченко, О. Хохліної, Н. Фелінської, Л. Шипової та ін.; дослідженням різних аспектів агресивної поведінки дітей 3 порушенням інтелектуального розвитку займались $\quad$ В. Коваленко, Л. Кузнецова, В. Лебединський, Н. Максимова, О. Мамічева, К. Мілютіна, Г. Міненко, М. Мухіна, Н. Серомаха, С. Стребелєва, В. Піскун, К. Поспішиль, Л. Прохоренко, С. Рубінштейн, I. Татьянчикова, С. Трикоз, В. Худик, О. Чеботарьова, М. Федоренко, Л. Шипіцина, В. Шибецька та ін.

Mema cmammi полягає у висвітленні особливостей діагностики агресивної поведінки як виду поведінкових розладів дошкільників 3 порушеннями інтелектуального розвитку.

Виклад основного матеріалу. У дослідженні взяло участь 159 осіб, iз них 7 вихователів, 7 корекційних педагогів, 7 практичних психологів, 52 батьків та 86 дітей старшого дошкільного віку 3 порушеннями інтелектуального розвитку.

Діагностика агресивної поведінки дітей 3 порушеннями інтелектуального розвитку проводилася за виділеними нами діагностичними критеріями: взаємини 3 однолітками та дорослими, самоконтроль, дисциплінованість, локус контролю, емоційний стан та особистісні якості.

Відповідно нами було виділено такі завдання дослідження:

- визначити рівень розвитку самоконтролю дітей;

- визначити рівень розвитку дисциплінованості дошкільників;

- визначити спрямованість локус контролю досліджуваних;

- визначити особливості особистісної сфери та виділити риси, які відображають наявність агресивної поведінки;

- визначити особливості взаємин дитини з іншими.

Розглянемо більш детально діагностику за кожним критерієм.

Рівень самоконтролю визначався за допомогою методики «Ланцюг дій». Методика проводиться індивідуально. Дитині в доброзичливих умовах повільно та чітко надається інструкція, яка передбачає виконання низки послідовних дій. За потреби інструкція може повторюватися, але лише до початку виконання завдання. Під час виконання самого завдання жодні підказки чи доповнення дитині не даються. Фіксуються лише ті помилки, які дошкільник не помітив та не виправив.

Отримані дані проведеної діагностики рівня самоконтролю дітей старшого дошкільного віку з порушеннями інтелектуального розвитку за методикою «Ланцюг дій» показали, що лише $3,5 \%$ дошкільників 3 порушенням інтелектуального розвитку мають достатній рівень розвитку 


\section{Psychology}

самоконтролю. Своєю чергою, середній рівень розвитку самоконтролю виявлений у 27,9\% дошкільників 3 порушенням інтелектуального розвитку. Решта дітей показали низький рівень розвитку самоконтролю та неможливість виконання завдання без сторонньої допомоги $(68,6$ \%).

3 метою діагностики типу спрямованості локусу контролю у дітей старшого дошкільного віку з порушеннями інтелектуального розвитку ми використали методику «Одного разу» [Яценко, 2003]. Методика проводилася індивідуально з кожною дитиною. Дошкільнику зачитувалися 9 ситуацій та одночасно викладалися (відповідні до розповіді) картки. Кожна ситуація ставила дитину перед необхідністю вибору 3 двох альтернативних причин іiі виникнення. Аналіз виборів дитини здійснювався за допомогою ключа методики, який відповідає двом основним спрямованостям локусу контролю особистості дитини:

За результатами дослідження спрямованості локус контролю старших дошкільників з порушенням інтелектуального розвитку за цією методикою виявлено, що 82,5 \% дітей мають екстернальну (зовнішню) спрямованість локусу контролю. Відповідно інтернальну (внутрішню) $17,5 \%$.

Для дослідження якостей особистості дошкільника 3 порушеннями інтелектуального розвитку ми використали проективну методику «Кактус», адаптовану до дітей даної категорії [Руденко, 2012]. На відміну від звичайної (неадаптованої), ця методика передбачала попередню роботу, яка містила розгляд ілюстрацій, самого кактусу та його обговорення (який кактус буває, якого він кольору, що в нього є тощо), після чого дитина починала малювати власний кактус. Після завершення малюнка кожній дитині ставилися уточнювальні запитання, які мали на меті розкриття наявних проблем. Методика проводилася індивідуально. При аналізі результатів проективної методики враховувалося: просторове положення, розмір малюнка, характер ліній, сила натиску олівців, характеристика самого кактусу (домашній чи дикий), характеристика манери малювання (промальований чи схематичний), характеристика голок (розмір, розташування, положення).

Аналіз малюнків дітей 3 порушенням інтелектуального розвитку дозволив зробити висновки про те, що для більшості продіагностованих дошкільників 3 інтелектуальними порушеннями притаманна агресивність $(62,8 \%)$, імпульсивність $(87,2 \%)$ та тривожність $(81,4 \%)$. За іншими показниками можна простежити певні тенденції: більшість дітей 3 показником егоцентризму (36\% досліджуваних) мають високий рівень прояву демонстративності. Залежність та невпевненість проявляється у 48,8 \% дошкільників. Проективна методика показала, що такі риси, як скритність, обережність проявляється у 37,1\% досліджуваних дітей 3 порушеннями інтелектуального розвитку.

Комплексна діагностика емоційно-особистісної сфери дитини за методикою «Кактус» дала можливість не лише визначити наявність 
проявів агресивності, тривожності та імпульсивності, але й усебічно вивчити особистість старшого дошкільника 3 порушеннями інтелектуального розвитку.

3 метою оцінки рівня дисциплінованості дітей дошкільного віку 3 порушеннями інтелектуального розвитку нами було застосовано експертну оцінку. До експертної групи входили вихователі, дефектологи та психологи, які працюють 3 цими дітьми.

Експертна оцінка будувалася на основі результатів спостереження за дитиною протягом шести місяців. Спостереження здійснювалося за схемою, яка передбачала аналіз поведінки дошкільника 3 порушеннями інтелектуального розвитку під час занять та вільної гри. У ході спостереження фіксувався вид порушення норм поведінки та систематичність їх проявів. На основі аналізу спостережень було виділено три рівні дисциплінованості старших дошкільників 3 порушеннями інтелектуального розвитку: достатній, середній та низький.

44,1 \% дітей, які характеризувалися низьким рівнем знань норм і правил поведінки, моральних цінностей, низьким рівнем мотивації застосування цих норм та правил у житті, відсутністю критичного ставлення до того, що заборонено, неусвідомленням відповідальності за власну поведінку, частими порушеннями дисципліни на заняттях, суперечками 3 дорослими, частими бійками та конфліктами з однолітками, експерти віднесли до групи дошкільників 3 низьким рівнем розвитку дисциплінованості.

Відсоток дітей з порушенням інтелектуального розвитку із середнім рівнем розвитку дисциплінованості склав 32,5\%. Дошкільники 3 інтелектуальними порушеннями 3 середнім рівнем розвитку дисциплінованості мають мінімальний рівень моральних і поведінкових норм та цінностей, вони знають їх, можуть відрізнити «погані» та «добрі» вчинки, але не можуть наявні знання застосовувати на практиці (або можуть лише у відомій для них ситуації). Порушення дисципліни відбувається часто, проте такі дошкільники реагують на зауваження збоку та можуть корегувати власну поведінку відносно інструкцій дорослого. Група дітей, що склала достатній рівень дисциплінованості, досить незначна - 23,4\%, такі діти мають лише ситуативні порушення дисципліни, які не мають генералізованого та систематичного характеру.

Для діагностики особливостей взаємин дітей старшого дошкільного віку з порушеннями інтелектуального розвитку з батьками та однолітками нами було використано методику Рене Жиля [Яценко, 2003]. Ця методика $є$ проективно-візуальною, що полегшує сам процес діагностики дошкільників 3 порушеннями інтелектуального розвитку. Стимульний матеріал методики складається 3 картинок, на яких зображені діти і дорослі, а також тестових завдань, спрямованих на виявлення особливостей поведінки в різноманітних життєвих ситуаціях, актуальних для дитини, та їі взаємин з іншими людьми. Дитина повинна вибрати собі 


\section{Psychology}

місце серед зображених людей або ідентифікувати себе з персонажем, який займає те або інше місце в групі. Вона може вибрати його ближче або дальше від певної особи. У текстових завданнях дитині пропонується вибрати типову форму поведінки, причому деякі завдання будуються за типом соціометричних. Отже, методика дозволяє одержати інформацію про ставлення дитини до різних людей, які іiі оточують (сімейного оточення), і явищ.

Крім якісної оцінки результатів, усі показники одержують своє кількісне вираження.

Результати діагностики умовно розділені на дві частини: показники, що характеризують конкретно-особистісні взаємини дитини з іншими людьми: матір'ю, батьком, обома батьками (як родини), братами і сестрами, бабусею і дідусем, іншими (подругою); та показники, що характеризують особливості самої дитини: допитливість, прагнення до домінування в групі, прагнення до спілкування 3 іншими людьми у великих групах, відстороненість, прагнення до самоти, соціальна адекватність поведінки.

За показниками, що відображають конкретно-особистісне ставлення дошкільника до інших, нами було виділено три групи: позитивне, негативне та індиферентне ставлення. Результати за діагностикою показників ставлення дитини до інших за методикою Рене Жиля представлено в табл. 1.

Таблиия 1

Особливості взаємин дітей з порушеннями інтелектуального розвитку з однолітками та дорослими за методикою Рене Жиля

\begin{tabular}{|c|c|c|c|c|c|c|c|}
\hline \multirow[b]{2}{*}{$\begin{array}{l}\text { № } \\
\text { шкал }\end{array}$} & \multirow[b]{2}{*}{ Ставлення } & \multicolumn{2}{|c|}{ Позитивне } & \multicolumn{2}{|c|}{ Індиферентне } & \multicolumn{2}{|c|}{ Негативне } \\
\hline & & $\begin{array}{l}\text { K- } \\
\text { сть }\end{array}$ & $\%$ & $\begin{array}{l}\text { К- } \\
\text { сть }\end{array}$ & $\%$ & $\begin{array}{l}\text { K- } \\
\text { сть }\end{array}$ & $\%$ \\
\hline 1 & Ставлення до матері & 61 & 71 & 16 & 18,6 & 9 & 10,4 \\
\hline 2 & Ставлення до батька & 27 & 31,4 & 30 & 34,9 & 29 & 33,7 \\
\hline 3 & $\begin{array}{l}\text { Ставлення до матері } \\
\text { й батька як } \\
\text { батьківської пари }\end{array}$ & 45 & 52,3 & 23 & 26,7 & 18 & 21 \\
\hline 4 & $\begin{array}{l}\text { Ставлення до братів і } \\
\text { сестер }\end{array}$ & 34 & 39,5 & 30 & 34,9 & 22 & 25,6 \\
\hline 5 & $\begin{array}{l}\text { Ставлення до бабусі } \\
\text { й дідуся }\end{array}$ & 44 & 51,2 & 23 & 26,7 & 19 & 22,1 \\
\hline 6 & $\begin{array}{l}\text { Ставлення } \\
\text { однолітків }\end{array}$ & 42 & 48,8 & 22 & 25,6 & 22 & 25,6 \\
\hline 7 & $\begin{array}{l}\text { Ставлення } \\
\text { вихователя }\end{array}$ & 50 & 58,1 & 21 & 24,4 & 15 & 17,5 \\
\hline
\end{tabular}


При аналізі отриманих даних використовувалися не лише кількісні показники за кожною шкалою, але й відповіді дітей на додаткові уточнювальні запитання та дані, отримані під час збору анамнезу дошкільників 3 порушеннями інтелектуального розвитку.

Аналіз результатів за показниками, які відображають особистісні особливості дитини старшого дошкільного віку за методикою Рене Жиля, здійснювався також на основі кількісного та якісного аналізу відповідей дитини.

Особистісні показники за шкалою «прагнення до домінантності» виявлено в 53,5 \% дітей з порушеннями інтелектуального розвитку, окрім того, чітко простежується вирішення цієї потреби через застосування фізичної агресії.

За шкалою «товариськість» у 48,8 \% дітей старшого дошкільного віку виявлено такі риси, як дружелюбність, бажання та потреба в спілкуванні з іншими.

Закритість, відгородженість діагностовано в 46,5 \% дошкільників 3 порушеннями інтелектуального розвитку. При виконанні методики такі діти завжди розташовували себе якомога далі від інших, на самоті, малювали на картці лінії, що їх відокремлювали. На додаткові запитання діти цієї групи не бажали відповідати, у деяких серед цих дошкільників спостерігалося чітко виражене негативне ставлення до конкретних осіб (закреслювали батька, друга чи вихователя). Соціальна адекватність поведінки розглядається як система взаємопов'язаних дій та вчинків особистості, що відображає вміння адекватно поводитися у суспільстві, відповідати вимогам та очікуванням свого оточення, володіти та засвоювати соціальні шаблони поведінки, які притаманні цьому соціальному середовищу. Елементи соціальної адекватності поведінки як результату цілеспрямованого спеціально організованого психолого-педагогічного впливу зафіксовано лише в 12,7 \% дітей 3 порушенням інтелектуального розвитку. Таким дошкільникам притаманна невідповідність реакцій на події, незнання поведінкових норм, а в разі наявності знань - низька мотивація до їх використання.

Оскільки діагностика емоційної сфери дітей дошкільного віку 3 порушеннями інтелектуального розвитку вже частково здійснювалася при використанні попередніх методик («Кактус», методика Рене Жиля), то було вирішено використати методику, яка спрямована безпосередньо на діагностику негативних емоційних станів (спалахи гніву, злості, агресії). 3 цією метою проведено анкетування експертів (батьків, вихователів, психологів) за допомогою методики «Анкета визначення рівня тривожності» та «Анкета визначення рівня агресивності» (Г. Лаврентьєва та Т. Титаренко) [Яценко, 2003]. Загальна оцінка для кожної дитини визначалася як середнє арифметичне результатів трьох анкет.

За результатами анкетування експертів за методикою «Анкета визначення рівня агресивності» (Г. Лаврентьєва та Т. Титаренко) виявлено такі дані: високий рівень агресивності притаманний $71 \%$ дітей 3 


\section{Psychology}

порушеннями інтелектуального розвитку, середній рівень $-19,7$ \%, і лише 9,3 \% дошкільників мали низький рівень агресивності.

За результатами анкетування експертів виявлено, що високий рівень тривожності притаманний більшості досліджуваних дітей 3 порушеннями інтелектуального розвитку $(86,1 \%)$. За анкетними даними 9,3\% дошкільників мали середній рівень тривожності і лише $4,6 \%$ низький.

Зазначимо, що показники за результатами трьох анкетувань для кожної дитини суттєво не відрізнялися у вихователів та психологів, дещо відмінні результати дало анкетування батьків. 3 метою забезпечення об'єктивності враховано результати всіх трьох анкет.

На основі отриманих даних нами було виділено рівні сформованості агресивної поведінки, які наочно представлено на рис. 1.

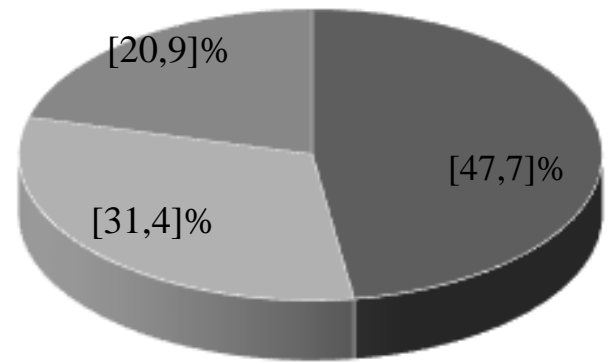

Рис. 1. Рівні сформованості агресивної поведінки дітей 3 порушеннями інтелектуального розвитку.

До групи дітей старшого дошкільного віку 3 порушеннями інтелектуального розвитку, які мають високий рівень агресивної поведінки, віднесено дошкільників, які одночасно мають порушення самоконтролю (низький рівень розвитку самоконтролю), зовнішній локус контролю, систематичні та генералізовані порушення норм поведінки (низький рівень розвитку дисципліни), порушення взаємин з батьками та однолітками, переважання негативного емоційного фону з частими спалахами гніву, агресії, злості та високим рівнем тривожності (високий рівень), а також хоча $б$ три 3 перерахованих особистісних якостей: демонстративність, егоцентризм, імпульсивність, скритість, агресивність, відчуженість, мстивість, прагнення до домінування. Отже, ми отримали групу дітей, що відповідає цим характеристикам $-47,7 \%$ дітей 3 інтелектуальними порушеннями.

До групи дітей старшого дошкільного віку 3 порушеннями інтелектуального розвитку, які мають середній рівень агресивної поведінки, ми віднесли дошкільників, для яких характерно: порушення самоконтролю (середній рівень розвитку самоконтролю), зовнішній локус контролю, порушення поведінки, які не мають систематичного характеру та 
проявляються переважно лише в одній сфері життєдіяльності (наприклад, лише вдома чи лише на заняттях), порушення взаємин з однією з груп (або 3 дорослими, або 3 однолітками), середній рівень тривожності та агресивності, негативні особистісні риси, що проявляються лише за певних умов (наприклад, в незнайомій ситуації чи 3 незнайомими людьми). Отримані результати свідчать, що середній рівень характерний $31,4 \%$ дошкільників 3 порушеннями інтелектуального розвитку.

До групи дітей дошкільного віку з порушеннями інтелектуального розвитку, які мають низький рівень агресивної поведінки, ми віднесли дошкільників, які мають сформовані елементарні навички самоконтролю (достатній рівень), внутрішній локус контролю, достатній рівень розвитку дисциплінованості, низький рівень тривожності та агресивності, а серед особистісних якостей переважає товариськість, дружелюбність. За наявності низького рівня агресивної поведінки порушення взаємин 3 батьками чи однолітками має лише ситуативний характер, а в дітей наявне позитивне ставлення до батьків та друзів. За результатами дослідження низький рівень агресивної поведінки притаманний 20,9\% дітей старшого дошкільного віку з порушеннями інтелектуального розвитку.

Висновки та перспективи подальиих наукових розвідок. Агресивна поведінка - один із найрозповсюдженіших видів поведінкових розладів серед дітей 3 порушеннями інтелектуального розвитку. До основних проявів агресивної поведінки належать порушення розвитку самоконтролю, взаємин з однолітками та батьками, зовнішній локус контролю, переважання негативного емоційного фону та наявність негативних особистісних рис. Проведене дослідження виявило, що переважна більшість респондентів мають високий рівень сформованості агресивної поведінки. Перспективу подальших наукових розвідок вбачаємо у теоретичному обгрунтуванні та експериментальному впровадженні мультимодальної психокорекційної програми для зниження рівня розвитку агресивної поведінки дітей дошкільного віку 3 порушеннями інтелектуального розвитку.

\section{ЛІТЕРАТУРА}

Дидактичні та методичні..., 2014 - Дидактичні та методичні засади спеціальної освіти розумово відсталих дошкільників: нав.-метод. посіб. / Г. Блеч, І. Бобренко, А. Висоцька, I. Гладненко, Н. Макарчук, А. Міненко, С. Трикоз, О. Чеботраьова. Київ : Інститут спеціальної педагогіки НАПН України, 2014. 337 с.

Психологія розумово..., 2008 - Психологія розумово відсталої дитини: підручник / В. Синьов, М. Матвєєва, О. Хохліна. Київ : Знання, 2008. 359 с.

Руденко, 2012 - Руденко Л. М. Генезис агресивної поведінки у розумово відсталих дітей та ії вплив на процеси життєдіяльності. Актуальні питання корекційної освіти. 2012. Вип. 3. С. 362-372.

Руденко, 2010 - Руденко Л. М. Клініко-психологічні аспекти класифікації розладів поведінки. Науковий часопис Національного педагогічного університету імені М. П. Драгоманова. Серія 19 : Корекційна педагогіка та спеціальна психологія. 2010. Вип. 16. С. 309-312.

Смирнова, 2003 - Смирнова Т. П. Психологическая коррекция агрессивного поведения детей. Серия «Психологический практикум». Ростов н/Д : «Феникс», 2003. 160 с. 
Яценко, 2003 - Яценко Т. В. Діагностика психічного розвитку дітей дошкільного віку: методичний посібник [Електронний pecypc]. Режим доступу : http://blankiua.com.ua/other/2033/index.html.

\title{
REFERENCES
}

Dydaktychni ta metodychni..., 2014 - Dydaktychni ta metodychni zasady spetsialnoi osvity rozumovo vidstalykh doshkilnykiv: nav.-metod. posib. / H. Blech, I. Bobrenko, A. Vysotska, I. Hladnenko, N. Makarchuk, A. Minenko, S. Trykoz, O. Chebotraova. Kyiv : Instytut spetsialnoi pedahohiky NAPN Ukrainy, 2014. 337 s.

Psykholohiia rozumovo..., 2008 - Psykholohiia rozumovo vidstaloi dytyny: pidruchnyk / V. Synov, M. Matvieieva, O. Khokhlina. Kyiv : Znannia, 2008. 359 s.

Rudenko, 2012 - Rudenko L. M. Henezys ahresyvnoi povedinky u rozumovo vidstalykh ditei ta yii vplyv na protsesy zhyttiediialnosti. Aktualni pytannia korektsiinoi osvity. 2012. Vyp. 3. S. 362-372.

Rudenko, 2010 - Rudenko L. M. Kliniko-psykholohichni aspekty klasyfikatsii rozladiv povedinky. Naukovyi chasopys Natsionalnoho pedahohichnoho universytetu imeni M. P. Drahomanova. Seriia 19: Korektsiina pedahohika ta spetsialna psykholohiia. 2010. Vyp. 16. S. 309-312.

Smyrnova, 2003 - Smyrnova T. P. Psykholohycheskaia korrektsyia ahressyvnoho povedenyia detei. Seryia «Psykholohycheskyi praktykum». Rostov n/D : «Fenyks», 2003. $160 \mathrm{~s}$.

Yatsenko, 2003 - Yatsenko T. V. Diahnostyka psykhichnoho rozvytku ditei doshkilnoho viku: metodychnyi posibnyk [Elektronnyi resurs]. Rezhym dostupu : http://blankiua.com.ua/other/2033/index.html.

UDK 159.923.2:316.625

DOI 10.31470/2308-5126-2019-42-1-16-27

\author{
Ірина Боровинська, \\ аспірант Інституту сочіальної \\ та політичної психологї \\ НАПН України
}

Iryna Borovynska,

PhD Student, Institute for Social and Political Psychology of NAES of Ukraine

E-mail: i.borovynska@gmail.com ORCID 0000-0002-7280-0424

\begin{abstract}
Для вирішення завдань, поставлених у статті, а саме: з'ясувати, яке місие у структурі життєвої успішності займають здоров'я та ментальне здоров'я, визначити чи існують якісь негативні наслідки прагнення до життєвої успішності $i$ як вони можуть вплинути на ментальне здоров'я людини, було проаналізовано різні підходи до розуміння понять «здоров'я» та «ментальне здоров'я». Досліджено місие і роль ментального здоров'я у загальній концепиії життєвої успішності. Проаналізовано можливі негативні наслідки впливу гонитви за життєвим успіхом на психічне здоров'я людини. У ході теоретичної розвідки встановлено, щзо здоров'я і ментальне здоров'я трактуються не як відсутність захворювань, а як більш комплексне явище. У той самий час ментальне здоров'я розглянуто як інтегральну частину здоров'я та виділено наступні його компоненти: позитивне ставлення до самого себе, розвиток, самоактуалізачія і самореалізація, персональна автономія, емпатія, гуманність та здатність взаємодіяти з іншими, здатність виконувати життєві завдання, саморегуляція тощзо. Визначено аспекти, через які проявляється зв'язок ментального здоров'я з процесом досягнення життєвої успішності. Серед них виділено особистісний аспект, який включає в себе когнітивні функиії, афективні функиї̈, поведінку, прагнення реалізуватися, а також міжособистісний (або соиіально-психологічний) аспект, який полягає у здатності створювати $i$ підтримувати
\end{abstract}

